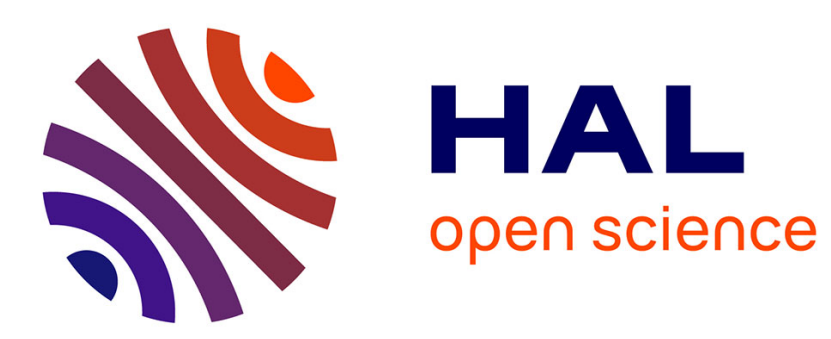

\title{
The shortcomings of the corporate standard: towards new enterprise frameworks?'
}

Blanche Segrestin, Armand Hatchuel

\section{To cite this version:}

Blanche Segrestin, Armand Hatchuel. The shortcomings of the corporate standard: towards new enterprise frameworks?'. International Review of Applied Economics, 2008, 22 (8), pp.429-445. 10.1080/02692170802137547. hal-00737108

HAL Id: hal-00737108

https://hal-mines-paristech.archives-ouvertes.fr/hal-00737108

Submitted on 10 Dec 2018

HAL is a multi-disciplinary open access archive for the deposit and dissemination of scientific research documents, whether they are published or not. The documents may come from teaching and research institutions in France or abroad, or from public or private research centers.
L'archive ouverte pluridisciplinaire HAL, est destinée au dépôt et à la diffusion de documents scientifiques de niveau recherche, publiés ou non, émanant des établissements d'enseignement et de recherche français ou étrangers, des laboratoires publics ou privés. 
THE SHORTCOMINGS OF THE CORPORATE STANDARD: TOWARDS NEW ENTREPRISE FRAMEWORKS?

\author{
Blanche Segrestin, Armand Hatchuel \\ blanche.segrestin@ensmp.fr, armand.hatchuel@ensmp.fr \\ Centre de Gestion Scientifique, Ecole des Mines de Paris \\ 60, Bd. Saint-Michel, 75272 Paris Cedex 06 \\ To be published : \\ International Review of Applied Economics, \\ 2008, vol. 23, n4 \\ Special issue on "Regulation and Governance of the firm"
}

\begin{abstract}
Summary
As corporate governance is more driven by shareholder-oriented principles, managers are expected to adopt new attitudes and to be more accountable to shareholders in terms of their strategies and decisions. Yet, when governance is seen primarily as a "corporate matter", it exclusively concerns the coalition of shareholders. This convergence towards the model of the public corporation raises major questions as it leaves aside collective activities and their value creation processes. Coordination, capabilities development and innovation are omitted in the prevalent representation of the corporation.
\end{abstract}

This omission is symptomatic of the confusion between the legal corporate model and the actual activities of the firm. In their own ways, both shareholders' and stakeholders' approaches of the firm refer to the legal framework of the public corporation. This article argues that the concept of the firm should be distinguished from its corporate forms. Going back to the basic nature of the firm, it suggests that a firm is a collective endeavour whose activities are directed by management to create new potentials. By challenging the public corporation as a relevant model for the governance of the firm, it indicates new possible and pluralist norms of governance.

Key words: enterprise, governance, corporation, corporate law, stakeholders, shareholder, management 


\section{THE SHORTCOMINGS OF THE CORPORATE STANDARD: TOWARDS NEW ENTREPRISE FRAMEWORKS?}

In spite of a number of persistent heterogeneities (Allen and Gale, 2000), it is clear that the principles of corporate governance are now driven by a standard, worldwide model. Some authors have even gone so far as to announce the "end of history for corporate law (Hansmann and Kraakman, 2000). They argue that, "although some differences may persist as a result of institutional or historical contingencies, the bulk of legal development worldwide will be towards a standard legal model of the corporation" as there is no more serious competitor to the "standard shareholder-oriented model".

Although provocative, this view is all the more challenging that the model of the publiclyowned corporation is now extremely widespread. Indeed, it has been adopted by all national corporate laws. Attempts to protect stakeholders against the primacy of shareholders mainly occur outside the sphere of corporate law, relying on other regulatory means (Winkler 2004). By only addressing relations between shareholders and management, corporate law has contributed to the ingrained conviction that shareholders are the legitimate owners of the firm. Consequently, the agency theory has provided a rationale for how modern organizations should be governed, primarily through improved monitoring and control, incentives, boards of directors and major shareholders.

In this paper, we would like to question this conception in which the governance of the firm is primarily viewed as a "corporate" matter and exclusively concerns a coalition of shareholders. Considering the productive and creative processes, we would specifically like to address the following issues:

1- The convergence around the corporate model may be fuelled by a confusion between the firm and one of its legal corporate forms, namely the public corporation. This corporate form conveys a fallacious representation of the firm. The shift from the governance of the firm to corporate governance can be explained by historical factors. But one has to keep in mind that the public corporation was originally thought of as a financing technique, and not a framework to support collective action.

2- Despite this discrepancy, corporate law has exerted a continual and wide-ranging influence on how firms are perceived. Governance is considered the domain of shareholders and managers; the separation between so-called corporate ownership and operational control is seen as an intrinsic feature of the firm. In our view, research in the field, including the literature on stakeholder theory, has continued to reinforce this bias; and it has for instance contributed to shaping the processes of governance reform (Menjuck, 2005; Roberts et al., 2005).

3- Today, recurrent crises and imbalances call for a new approach. The standard view of the corporation does not account for the value-creating processes which characterize the firm, especially in innovative contexts. The consensus concerning the standard view has to be theoretically challenged. Consequently, a new, more theoretically grounded vision of the firm is required. Such a vision would provide a framework for more wide-ranging approaches to collective governance. It would also provide legal 
forms of business organization better suited to the challenges of the present innovative context.

Recent work in management science has made it possible to reappraise these ambitious questions by considering the firm as a regime of collective action requiring collective and creative learning processes (David et al., 2000). It is not the purpose of this paper to discuss the economic theories of the firm., but it aims at providing a preliminary sketch of the fundamental features of the firm that could be used to construct a consistent governance framework, and to isolate a number of examples of possible alternative legal statutes.

The paper is organized as followed: in the first section, we briefly present both shareholders and stakeholders-oriented interpretations of the corporation. Despite notable exceptions, both approaches generally consider that the corporation allocates rights over collectively-produced wealth: neither of the approaches questions the corporation as the legitimate matrix of governance. Considering the prevalence of the public corporation, the second section analyses the emergence of the French public corporation (société anonyme): this historical detour shows that the creation of this legal framework has been motivated by very specific problems: to account for collective wealth-creating processes, it is necessary to formulate a more generic model of the firm. In the third section, we build on the literature to model the firm as a collective endeavour, which mobilizes various potentials by means of a flow of coordinated activities, to create collective wealth, regenerate potentials, and create new capabilities for future action. The link between activity flows and the generation of potentials can in no sense be taken for granted; it is, rather, the result of management actions. This generic characterization makes it possible to challenge the dominant corporate model. It also makes it possible to restore a variety of governance principles: in the fourth section, we show how new original governance frameworks can be derived from this model. We conclude by assessing the limits of our approach and indicating further research questions.

\section{The corporate model as a common reference both for stakeholders and shareholders theories of the firm}

\subsection{The corporation considered as a coalition of "owners"}

With the globalization of the financial markets, relations between managers and shareholders have become particularly tense. The series of financial scandals starting in 2000 has come as little surprise those who hold that managerial power is not monitored closely enough either by boards of directors or financial analysts. In the contractual view of the firm, these problems result from agency relationships with contracts - future behaviours, especially managerial conduct, cannot be fully specified in contracts (Hart, 1995). Since there is not enough competition to guarantee that financiers obtain a return, additional mechanisms (including legal institutions) are required (Shleifer and Vishny, 1997). In this respect, the work of Alchian and Demsetz has been highly influential (Alchian and Demsetz, 1972). Focusing on the risks of shirking within a team, they argue that firms are more efficient with specialized monitors who are rewarded with the "residual claim" (i.e. "net income after the payment of other inputs"). Similarly, in the public corporation, it would be more efficient to allocate residual claims to shareholders since they are not guaranteed any returns. According to Alchian and Demsetz, because shareholders are entitled to allocate residual income, they have a strong incentive to monitor the firm. Their approach has provided a convincing rationale to 
the prevailing principal-agent model of the public corporation which portrays the firm as a bundle of contracts between owner-agents and heterogeneous resources (Coriat and Weinstein, 1995; Jensen and Meckling, 1976). The dispersion of capital would give excessive powers to managers to the detriment of shareholders, who, due to insufficient information, would be incapable of exercising their authority.

Thus, corporate governance is defined as the process that "deals with the ways in which suppliers of finance to corporations assure themselves of getting a return on their investment" (Schleifer and Vishny, 1986): its primary focus is to protect those who provide capital to the firm (Bradley et al., 1999).

\subsection{The fallacious notion of the ownership of the firm}

As residual claimants, shareholders are thus considered as the legitimate owners of the corporation: they would be entitled to insist that the firm must be run in their interests. However, the idea that shareholders are owners is a fallacious one. According to the law, while shareholders do own their shares, they do not own either the assets used by the firm or the wealth it generates: the ownership model is both a technical mistake (Parkinson, 2003; Ripert, 1951) and a "normatively unacceptable” assumption (Donaldson and Preston, 1995).

In spite of its erroneous nature, the ownership model has been promoted by economic theories and regulatory policy. Courts have regularly ruled in favour of saver-shareholders to ensure that they have voting rights, to guarantee a certain degree of transparency, and to make certain that they have a real influence on firms' behaviour. Hence the recent debate concerning best practices in corporate governance. The burgeoning number of regulatory and evaluative frameworks has signalled an ever-closer surveillance of the activities of managers, even as the foundations for such an approach have become increasingly controversial (Aglietta and Rebérioux, 2005).

\subsection{From shareholders to stakeholders: A perpetuation of the corporate model}

\section{Shareholder value and crises in the firm}

This view of the corporation has provoked debate and experimentation in the field of corporate law throughout the $20^{\text {th }}$ century. While investors, who control fluid and negotiable equities, are at liberty to look for promising and, ideally, risk-free prospects, employees are forced to live with ever-increasing levels of job insecurity. The propensity to maximise "shareholder value" provokes brutal and pre-emptive strategic shifts (Batsch, 2002) it also encourages the splitting of companies into independent entities that can more easily be sold off. In this "neo-company" model (Hatchuel, 2004), the collective processes which create value are largely occluded. Everything is treated as if the value of the firm was measured in terms of financial flows; "intangible" or immaterial assets ranging from brands to skills, assets on which the future of the firm depends, are left out of the equation. As (Krafft and Ravix, 2005) observed, "the shareholder value principles generate a restricted vision of corporate governance" and "this restricted vision applied in practice drove innovative industries into high turbulences” (p.126).

\section{The debate concerning worker participation}

In this context, commentators have long defended the idea of integrating employees into 
corporate governance. The notion was mooted that employees should be aggregated to their companies - owners of their jobs, they could not be deprived of them without just cause (Logue and Yates, 2001). Employment law has continually developed legislation on dismissal, unfair sacking, etc. But the integration of employees also implies their involvement in the firm's decision-making processes. The arguments are familiar: it is not enough merely to inform and consult employees; they must also have a deliberative voice on the board of directors. A number of authors have called for a profound revision of the modalities of representation, some even suggesting co-management (Aglietta and Rebérioux, 2005; BlochLainé, 1963; Rebérioux, 2003). But the idea of worker participation has gradually lost impetus, undermined by a growing belief that it is inefficient. Today, the participatory role is expected to be filled by employee-shareholders, an approach that reinforces the basic corporate structure.

\section{From workers to stakeholders}

However, over the last few decades, a number of ideas which challenge the primacy of shareholders have gained ground. Throughout the history of capitalism there have been many attempts to regulate relations between the firm and the various components of the social body (employees, adjacent owners, host territories, civil society in general) and to integrate the aims and interests of various stakeholders. From the first cooperative and associative movements (Gide, 1910, 1911) to recent "stakeholders" companies (Donaldson and Preston, 1995; Hill and Jones, 1992), corporate governance has tended to integrate ever-wider categories of individuals (Jones and Wicks, 1999; Kochan and Rubinstein, 2000). As (Hansmann and Kraakman, 2000) observed, stakeholder models are often combinations of old labour-oriented models. But the normative ambitions inherent in the concept of the stakeholder go far beyond this.

The stakeholder concept, which first emerged in the 1960s, seeks to redefine stakes and rights amongst the parties beyond the scope of shareholders. Initially, the definition of the term was very broad, embracing all groups affecting or affected by the activities of the firm. But academics have since narrowed the terms. For instance, (Post et al., 2002a) define stakeholders as "individuals and constituencies that contribute, either voluntarily or involuntarily, to its wealth-creating capacity and activities, and who are therefore its potential beneficiaries and/or risk bearers". This is consistent with (Kochan and Rubinstein, 2000) who identify genuine stakeholders as individuals who simultaneously supply critical, valued resources, place something "at risk", and have sufficient organizational clout to influence the performance of the firm.

In our view, although they have been criticized for their heterogeneous and controversial views (Stoney and Winstanley, 2001), stakeholder theories have provided critical new insights in the debate. However, it is worth noting that these theories do not fundamentally question the corporate model; they tend either to broaden the definition of holders of property rights or justify the corporation as a means of allocating rights of control rather than of property.

\section{Extending property rights to stakeholders}

One important issue in stakeholder theory is the extension of property rights to parties other than shareholders. Based on agency theory, Hill and Jones have developed a "stakeholderagency theory" (Hill and Jones, 1992). According to this approach, managers "can be seen as the agents of [all] other stakeholders." Hill and Jones argue that credible commitments and various institutional devices are required to align diverging interests but that stakeholders 
differ among themselves with respect to the importance of their stake in the firm and their power vis-à-vis the managers.

In their famous article, Donaldson and Preston clarified the purpose of stakeholder theory, arguing that it is more effective when based on normative considerations (Donaldson and Preston, 1995). Following the work of Becker on human capital (Becker, 1964), they broadened the scope of the theory of property rights. In their view, ownership cannot be restricted to share-ownership and financial capital. "The stake of long-term employees who have worked to build and maintain a successful business operation [...], the stake of people living in the surrounding community" is what, for them, constitutes the newly defined property rights. And they add: "one needs not make the more radical assertion that such stakes constitute formal or legal property rights [...]. All that is necessary is to show that such characteristics [...] give various groups a moral interest [stake] in the affairs of the corporation” (p. 85).

Going further, Kochan and Rubinstein observe that moral values are not enough to build an alternative framework for stakeholder companies. One pre-condition for managers to be effectively accountable to stakeholders is that "the value of the assets must be affected by the fate of the enterprise so that its owners can legitimately claim a "property right" for putting their assets at risk" (Kochan and Rubinstein, 2000, p.373). Another is that stakeholders have effective power in the organization. In our view, these proposals are problematic in that they imply the same kind of bias inherent to the old shareholder-oriented model: they tend to reinforce the "ownership" model and adapt the corporation model by broadening the circle of "principals" without questioning the primacy of property over collective wealth.

\section{Disentangling property rights and control rights: An updated vision of the corporation}

However, in a more recent article, Blair and Stout modified the argument. Returning to the essence of the firm considered as a collective activity - a "team production" - the authors commence their well-known article with the question: "who owns the corporation?" (Blair and Stout, 1999). In their model, to make collective action possible in spite of opportunism, and to create the necessary conditions for firm-specific investments, the firm must give grants on the way the collective rent will be allocated. The corporation is seen as a "mediating hierarchy" working as an internal governance structure. In this perspective, "corporate assets belong not to shareholders but to the corporation itself" (p.753). Team members voluntarily transfer their decisional and property rights to the neutral hierarch who is under control neither of shareholders nor of other stakeholders, because this is the most effective way of ensuring that complex public corporations are successful. As Kochan summarizes, "the authors explain that all stakeholders are prepared to surrender power and make firm-specific investments to achieve the enormous benefit of team production, and accept that an independent mediating hierarch will protect them in situations for which they cannot expressly contract in advance” (Kochan, 1999).

Blair and Stout's analysis represents a clear step beyond the traditional shareholdersprincipals model. They do not subscribe to the ownership model. Yet neither do they challenge the public corporation as a means of allocating control rights to shareholders: the public corporation entitles shareholders to mandate directors and control managers. Responsibility for corporate governance is assigned to shareholders, and shareholders alone have the right to modify company statutes and monitor strategic decisions. Although this approach encourages an increasingly dominant role for shareholders in that it renders 
directors accountable to them (Kaufman and Englander, 2005), Blair and Stout still consider the public corporation as the ultimate matrix for governance.

\subsection{From firm to corporation: A problematic restriction}

Most researches assume that the corporate legal framework is a valid model for the firm. But a firm isn't just a corporate contract among corporate partners. Why have corporate template and shareowners ended up with such a prevalent role? Couldn't the governance be perceived as a firm matter rather than a corporate matter ?

At this stage, our assumption is that existing theories may be mislead by the legal form of corporation and undermined by the absence of alternative frameworks of the firm: there is actually no law covering the 'enterprise' as such. Indeed, there is presently no legal framework defining an 'enterprise' as such. The firm only exists in the legal sphere through a raft of contracts (corporate contracts, labour contracts). In our view, this encourages a narrow approach to corporate governance, the act of governing being seen as exclusively a matter for partners-shareholders. The question is therefore: how, historically, did law come to be defined around the corporation rather than around the firm? Why have firms felt the need to take on the status of publicly-owned corporations?

\section{How the firm has been incorporated: The case of the French corporation ('société anonyme')}

What has historically given rise to the corporation, and especially to the publicly-owned corporation? A rigorous response to these questions would involve a review of business law in its entirety. Our ambitions are far more modest. Using traditional historical works ${ }^{1}$, we will limit ourselves to the case of the French public corporation, namely the société anonyme. The case is not instructive as a specific national corporate structure but as a representative instance of the common confusion between the corporate legal structure and the firm ${ }^{2}$. We will outline a few key stages in the emergence of the société anonyme to show that, historically, the figure of the partner has been progressively replaced by that of the shareholder.

\subsection{The origins of the limited liability partnership: a unique journey}

The idea of the "firm" as an association designed to harness a combination of individual contributions with a view to achieving particular goals is probably as old as humanity itself. In Antiquity, companies were exempt from the interdiction against interest (usury). In contradistinction to loan and lease contracts, companies made it possible to combine capital and credit, audacity and industry, and share the resulting profits. Unlike simple loans, risk was shared between partners who were neither dependent on nor subordinate to each other.

This initial concept opened the doors to any number of developments. The French Civil Code still defines a company as an association of several persons who "agree by contract to pursue a common enterprise focusing on goods or on their industry with a view to sharing profits or profiting from the business resulting from their endeavours.” But emphasis was soon placed on specific attributes leaving aside some unexplored alternatives. 


\section{Partnerships and solidarity}

Forming a partnership involves a large degree of risk. Consequently, mutual trust was a sine qua non for any company. The first companies were founded by brothers, or people who knew each other well, under the aegis of intuitu personae. Following Roman law, the concept of the firm was long based on family ties, and affectio societatis was a central tenet. In the Middle Ages, the circle of the compagnia was opened to brothers and cousins of partners and even to people from outside the family; but liability remained joint and unlimited. However, this kind of organization proved to be insufficiently open; it was an obstacle to the expansion of trading companies because its assets were limited (to those owned by its partners) and projects were overly vulnerable to the death of one of the partners.

\section{Limited liability used to mobilize capital}

Limited liability first emerged in maritime trading companies formed in order to undertake specific missions. In Antiquity, the commenda consisted in a provider of funds and a guarantor who undertook the journey. Third parties had no recourse against the provider of funds. This distinction opened the way to companies designed primarily to mobilize capital. The limited partnership made it possible for those precluded from commerce (the clergy, the aristocracy) to assume a discrete position in companies in which their liabilities were limited. In limited partnerships, partners' liability cannot exceed their contributions, a situation which makes it easier to raise capital from sources outside the company ${ }^{3}$.

It was also thanks to maritime law that the sale of partners' shares was introduced, notably with the development of joint ownership mechanisms in the $12^{\text {th }}$ and $13^{\text {th }}$ centuries. Insofar as land law was concerned, the transformation to the status of a company with no fixed purposes was effected through regular modifications to the articles of association coinciding with the death of individual partners. The invention of shares considerably encouraged the expansion of assignments and had the effect of ensuring that companies survived over longer periods of time than they had previously. Various kinds of limited partnerships with share capital rapidly appeared. The assignment of partners' shares did not, however, mean that those shares were freely negotiable.

It was only much later, with the advent of the railways, that partners were liable only for the total of their contributions (non-liability of partners) and that those contributions became negotiable. But how could partners of a company with share capital not be liable? How could guarantees be furnished to third parties? Corporations with share capital had been involved in a number of scandals in which savers had been defrauded by entrepreneurs who had willingly gone bankrupt in order to get their hands on the funds raised. After the introduction of regulations stipulating that firms should have at least a minimum level of registered capital, the authorities became obsessed with the question of how to protect the interests of savers. The task of designating administrators was explicitly accorded to shareholders who were also given the exclusive right to modify corporate statutes. However, the long and fastidious authorization process was abandoned in 1867, leaving the field open to the public corporation (société anonyme).

\subsection{The Société anonyme: An extreme version of the firm}

The public corporation is quite different from the initial concept of a collective venture. It is, 
in fact, a corporation with share capital rather than a partnership properly so called. Solidarity is diminished and intuitu personae dispensed with. With the recent invention of non-voting preferred stock, and participating or obligatory loans, the notion of partner has become even more flexible (Saintourens, 1987). Deprived of affectio societatis, shareholders paradoxically retain their status as partners without meeting the criteria required to be partners. By becoming simple financial contributors, shareholders are reduced to an extreme form of lenders. The corporation with share capital seems less a collective project and more a technique making it possible to "borrow" enormous amounts of money without undertaking to repay it. Thus, the public corporation cannot be confused with the concept of a firm. Strictly speaking, it is no more than a particular rationalization of the financing ${ }^{4}$ of a collective action.

This brief historical detour demonstrates how the law has progressively restricted the notions of "business corporation" and "partner". However, we are not saying that corporate models are inconsistent or illegitimate. On the contrary, the law is concerned primarily with legitimacy (Laufer, 2007); it addresses the possibility of creating conditions which encourage the involvement of various parties and the resolution of disputes. The law does not formalize action; rather, it formalizes the "conditions of cohesion" of the collective (Segrestin, 2006, 2005). In this context, the corporation is undeniably legitimate from the legal point of view. And our brief historical detour regarding the French case demonstrates that it is also a rational construction.

The fundamental problem is not, therefore, purely a legal one. From a social and managerial perspective, the corporate framework is problematic to the extent it is conceived as a general model of the firm. And this is misleading in that it fails to address other fundamental dimensions of collective action, notably value creation processes.

\subsection{Collective wealth-creating processes: What the corporation cannot account for}

Since the mid-19th century, the firm has become one of the most sophisticated forms of collective action. Recent research in the field of management science has highlighted the complex nature of the "metabolism" of innovative firms. The firm is not only a sphere of relationships and mutual commitments, but also an arena in which knowledge is produced and value created. Management science has outlined the importance of cognitive dynamics and innovative processes in collective organizations (Hatchuel and Weil, 1995)). Obliged to plan for the future, reduce risks, organize the capitalization of its experience, and build new areas of development, the firm works to ensure its own growth. It doesn't only consume resources; it also organizes collective design processes in order to develop new resources. It invents goods and procedures; it renews the expertise that it exploits. It creates new styles of living, new social and cultural practices. These processes are in no sense "natural". They go far beyond the relationships between managers and shareholders.

Reacting to the traditional micro-economic vision, evolutionist economic theory has underlined the role of intangible assets and skills in the value creation processes (Blair, 1995; Blair and Kochan, 2000). The firm's intent is “create, sustain and enhance its value-creating capacity” (Post, et al, 2002b, p.7). More recently, Krafft and Ravix suggested an evolutionary model in which the role of the manager is to organize production and innovative processes to ensure the viability of the firm (Krafft and Ravix, 2005). We would like to build on these approaches to formulate a new model of the firm. Such a model should account for the collective activities, for the entrepreneurial creative processes and the way they are managed. 


\section{Going back to some fundamental features of the firm}

Although many theories of the firm are now well-developed, scholars have rarely, to our knowledge, attempted to revise the corporate framework. Departing from the standard corporate model, we would like to return to some fundamental features of the firm. Although these features are far from being new, we believe that they can help us to reconsider the governance of the firm from an original perspective.

In order to retain only the most essential features in terms of governance, we will characterize the firm as follows: starting with initial "potentials" (capital, patents, expertise, brands, etc.), the firm develops activity flows oriented towards the production of new potentials guaranteeing its continued existence. Management is the ensemble of decisions and rules governing relations between activity flows and the regeneration of potentials. If we consider the firm as an entity which basically originates and implements recurrent collective actions, then capital and financial mechanisms are the conditions and consequences of the firm, even though they do not constitute its essence.

\subsection{Activity flows in the firm: Contributions and remunerations}

The firm can primarily be viewed as a multiplicity of activity flows. Activity flows cover all forms of work and exchange within specific time periods. In any given period, activity flows are formed and ordered into contributions to the collective activity. Individual activities can thus be perceived as existing within a collective framework; in return, the firm responds to the individual and collective activities of its participants by means of various kinds of remunerations.

\subsection{The creation of potentials: New values and new capacities for action}

A model delineating a series of balanced flows is, however, insufficient to describe the activity of the firm. The firm intends to transform past flows into potential future flows. Its aim is to create new value potentials or - which is the same thing - capacities for action resulting in the generation of value. In line with the notion of "organizational wealth" (Kaufman and Englander, 2005; Post et al., 2002b), the performance is to be measured in its capacity to create sustainable wealth, including intangible assets such as stable relationships with significant socio-political stakeholders. While flows are relative to a particular period, potentials are measured at a specific moment in time: a potential represents a series of promises for the future, but it can only exist and be realized in the present.

Attention should be drawn to one essential characteristic of potential: the firm mobilizes existing potentials in order to create new ones, but the creation of potentials necessarily requires the concourse of various activity flows. Potentials can only be generated through a combination of multiple activity flows, be they individual (for example, a sum of money or a skill) or collective (for example, a brand). This characteristic prompts the following remarks:

The notion of potential generalizes the notion of capital shares. It refers not only to the classical idea of profit but also to the development of further capabilities, including for instance staff skill or brand value. 
- Potentials may be either individual or collective, but they are not necessarily allocated on an a priori basis. Potentials generated by collective action do not belong ex ante to anyone in particular': while the accountable assets of the corporation are legally divided between shareholders after the firm has ceased trading, some potentials (such as brand value, goodwill, etc.) are collective and belong only to the firm as an entity. Secondly, while some potentials can be distributed among individuals, the process nevertheless depends on collective action and managerial decisions. For instance, an employee developing his or her skills, or an increase in the share value of the firm are dependent on strategic orientations and managerial capabilities. Other potentials, such as brands, are collective, and the firm as a legal body is the only entity which holds rights over them. Thirdly, and more fundamentally, because they always result from the coordination of various activities, new potentials are never imputable to particular individuals. They do not result from an accumulation of individual potentials, but, rather, from the management of various activity flows.

\subsection{Management for potential creation}

According to legal corporate templates, shareholders designate directors to coordinate the firm's activities and vote on important corporate matters, including issues relative to balance sheets; they also deliberate on the appropriateness of the orientations suggested by managers. Considering the paucity of these guidelines, it is clear that corporate law covers only a small fraction of managerial activities. It has long been known that managerial capacity is an essential feature of the firm which involves the intertwining of multiple levels of action and decision-making. We can, therefore, broaden our approach to management well beyond the scope of the present legal framework.

For a firm to exist there needs to be a link between activity flows and the creation of potentials. This link is the result of management decisions (Penrose, 1959) (Barnard, 1968; Kaufman and Englander, 2005). Firms are characterized by their intentional and objective use of various rationales to create potentials. Management capacity can thus be defined as the function linking activity flows to the creation of individual and collective potentials. But it is worthwhile to note that there are important prerequisites for this capability to be effective: to build new wealth, management needs the parties to agree to subordinate their individual potentials to managerial decisions ${ }^{6}$.

At this stage, we can sum up the basic features of the firm as follows ${ }^{7}$ :

- The firm is made up of all the individuals who have contracted reciprocal commitments relative to activity flows giving rise to contributions and remunerations, notably individuals who contribute with individual potential and those who participate in the management of the firm.

- $\quad$ The objective of the firm consists in boosting or recreating individual and collective potentials designated by its members.

- Management performance is regularly evaluated on the basis of potentials which have been selected and effectively developed: new fields of activity (new markets, new personnel, etc.) and new capacities for action (improved individual skills, the successful exploitation of capital, etc.).

- Governance rules should make it possible to modify the selection of potentials (within the legal framework). 


\section{Towards new legal alternatives for governance structures}

Due to its generic nature, this characterization of the firm embraces the whole range of legal definitions of business organizations. Our model can equally account for a PLC launching a public offer (and maximising shareholder value), for state-owned firms, or for cooperatives (whose potential is to be found in their capacity to develop their activities), and even for nonprofit associations (where the development of potential is non-capitalist and not allocated to the members). But the model doesn't only account for existing configurations. It can also be used to go beyond the traditional dichotomy between capital and labour to consider new approaches to the legal governance structure.

The model thus restores a broad range of governance possibilities, provided that rules defining legitimate conditions in terms of the sharing of risks, potentials and decision rights are applied. A large number of different configurations can be deduced by specifying the potentials and rights of the various members of the firm and, above all, by stipulating conditions of access to management. In order to develop this aspect and demonstrate the fecundity of our approach, we attempt to define and discuss a particular legal governance framework, that we have termed "Enterprise of Collective Progress" (ECP) (Hatchuel and Segrestin, 2007). This norm is especially designed to smooth out the major antagonisms that have marked the history of corporations, while bearing in mind that such a framework represents just one possible approach amongst a host of others.

In the corporation, shareholders are the main contracting parties. Even if they have no property rights, they do have voting rights, and are thus able to appoint and dismiss directors, which effectively means that they have the capacity to pre-empt the results of collective action. However, confusion between property and voting rights is not inevitable. We believe that it is more appropriate to distinguish different levels and rights in the governance of the firm:

- $\quad$ First, the identity of the members of the collective venture must be defined.

- $\quad$ Second, those members who, thanks to voting rights, are able, either directly or indirectly, to participate in the management process must be distinguished from the others.

- $\quad$ And third, those members who can legitimately claim responsibility for some of the potentials generated by collective activities must also be identified.

We will now consider these three groups separately.

\subsection{The members of the firm}

If the objective of the firm is to coordinate individual activity flows to transform them into wealth-creating processes, then the firm is made up of all those individuals who have contracted reciprocal commitments relative to activity flows. Therefore, participation in the firm doesn't necessarily depend on the contribution of financial potentials, but, rather, includes the exchange of a varied range of flows (loans, services, work, etc.). In this sense, not only employees, but also suppliers, banks, and some shareholders contribute to the firm, as do stakeholders whose rights may be temporarily impinged upon by the firm's activities.

\section{INSERT TABLE 1}

At this stage, two questions remained unanswered. On the one hand, who is legitimately able 
to play a role in management? And on the other, what rights and benefits can the various members of the firm expect?

\subsection{The beneficiaries of collective potentials}

Can our characterization of the firm resolve the confusion between contracting parties and beneficiaries? Corporate law is not very precise on the rights of shareholders in regard to surpluses generated by the firm. Traditional economic theories consider that they are the legitimate "residual claimants" as they assume the major financial risks (Alchian and Demsetz, 1972). But Blair and Stout have challenged this view. According to these authors, corporate law actually eliminates the role of the "principal”, imposing instead an internal and mediating governance structure (Blair and Stout, 1999).

To enforce the idea of collective welfare without shirking or free-riding, the notion of potential is useful as it re-establishes symmetry among the various contributions, be they capital, labour, expertise, employability, brands, etc. The following rules are suggested by our characterization of the firm:

o Participants own their initial potential and are remunerated for providing it to the firm. Each contribution calls for a balanced remuneration. But collaborators should also be able to benefit from the potentials they help to create.

o Collectively created potentials do not belong to specific individuals but to the collective entity. However, they can be shared out among various members of the firm with the proviso that the following principles are applied:

o They are shared among members of the firm in proportion to the individual potentials contributed.

o They are always shared with the collective entity. This original principle derives from the fact that the creation of potentials always results from collective action and is never entirely imputable to individual potentials; it is vital to develop further collective capabilities.

These principles have following properties: they do not designate specific beneficiaries according to a priori criteria: instead, they specify how the wealth can be legitimately shared according to the individual contributions to collective potentials. Besides, incentives are properly adjusted to avoid free-riding as each member is not only remunerated for their contribution but is also able to benefit from potential-sharing depending on their level of participation. More importantly, profit-sharing is consistent with the idea that new potentials never belong to anyone in particular as they are the result of coordinated collective actions whose purpose is to develop new potentials for further actions. Lastly, these principles may generate a number of unexpected effects: shareholders could be obliged to pay back a percentage of the added value from the sale of their shares to the firm. This rule would reduce the detrimental effects of speculation, as well as mechanically increasing the firm's capital and, consequently, its collective potential. But similarly, employees leaving the firm with increased skills and better prospects in the labour market could be obliged to pay a fee to the firm. ${ }^{8}$

INSERT TABLE 2 


\subsection{Corporate governance and participation in management}

In the standard corporate model, participation in management is a domain exclusively reserved to shareholders, who alone have the right to modify the statutes governing partnerships and to monitor strategic orientations. But, such a restriction is not compulsory. On the contrary, all potentials, be they individual or collective, should be taken into account. What kind of rules, then, should be applied in order to regulate the right to participate in management?

In order to avoid the current imbalances in corporate frameworks, all those contributing potentials should be able to apply for a managerial role. At the same time, a number of conditions should be met in order to ensure a sufficient level of affectio societatis. In this regard, certain scholars have argued that participation should be calculated in terms of individuals' degree of commitment to the firm (Bloch-Lainé, 1963). Others have attempted to draw a distinction between genuinely involved "stakeholders" wielding real influence and "latent stakeholders" (Kochan and Rubinstein, 2000). This distinction is an important one in terms of avoiding current imbalances in corporate frameworks and free-riding. We suggest the following rules:

- To be a partner in the ECP, one must both contribute a potential and demonstrate real commitment to the firm.

o Firstly, in order to participate in management, sufficient individual contributions would be necessary: shareholders would be required to provide a substantial financial investment and employees would have to provide substantial skills and competencies.

o Secondly, participation should depend on effective subordination. While Kochan and Rubinstein consider that genuine stakeholders supply critical, valued resources and have sufficient power in terms of organization to influence the performance of the firm (Kochan and Rubinstein, 2000), our model insists on the need for members to subordinate their potential to managerial decisions. Managers need to be given control over individual potentials. Such a stipulation would distinguish between stakeholders who subordinate their potential (the shareholders, the employees...) and stakeholders who do not (the banks, suppliers, consultants and independent workers...). Such a stipulation would imply that, in order to participate in management, shareholders would have to lose their right to anonymity, provide an investment spanning several years, and receive prior authorization whenever they wanted to take capital out of the firm. At the same time, employees would have to meet new requirements (based, for example, on seniority).

- How then can voting rights be distributed among participants who fulfil these conditions? Partners' voting rights are proportionate to shared potentials. This principle introduces a regulatory third party: the firm itself. Since collective potential can be greater than the sum of individual potentials (due to nonindividualized potential such as brands, patents, etc.), in our model collective potentials provide additional rights that are not allocated to any member in particular. These rights could be allocated either to shareholders or employees. However, in a different scenario, they could be allocated to the firm's directors. This 
would help to reduce the risk of free-riding and would also highlight the crucial role of management in building future capabilities.

\section{INSERT TABLE 3}

These rules clearly demonstrate the originality of the proposed model. It is equally clear that it will be necessary to simulate their effects and instigate a program of research designed to test the applicability of the model as a whole. But significantly, the model is consistent both with the reality of creative collective action and with a free and competitive market. The only real change involves the representation of the firm, which would now be cast as an entity based on collective action. Consequently, members' rights would depend on their activities and potentials. A firm would not belong to anybody in particular, but its members would benefit from the collective wealth it generated proportionally to their contributions and to the objectives that they were contributing to.

\section{Conclusion}

In this article, we have attempted to demonstrate that all current debates on corporate governance are based on the legal vision of the corporation, which cannot be merged with the concept of the firm. As corporate law is exclusively concerned with shareholders, the public corporation is not an appropriate model when it comes to thinking about the firm. Indeed, it could even be a fallacious model. The so-called ownership of the firm, which presumes that it should be managed for the benefit of its owners, is neither descriptively accurate nor normatively acceptable (Post et al., 2002b). The public corporation is more a financing technique than a template for creative collective action. And it induces crises which have frequently and predictably degenerated into social conflicts.

This is why new categories must be developed. An explicit model of the firm is required before designing and developing governance principles. Building on the theory of collective action, we have suggested a number of basic features of the firm, incorporating activity flows, individual and collective potentials, and management systems. These features are, we believe, consistent with wealth-creating collective processes and are relevant from the descriptive, instrumental and normative perspectives. The various corporate frameworks (publicly-owned corporations, closed corporations, workers' cooperatives, etc.) can be viewed as particular legal forms derived from this general model of the firm. In this article, we tried to show that this model makes it possible to generate a host of new legal corporate frameworks: for instance, it is possible to develop original approaches to profit-sharing. In the "Enterprise for collective progress", the rights of members of the firm would be based on the nature of their activities and the degree of potential that they contribute. The firm would not belong to anybody in particular, but its members would benefit from the collective wealth it generated proportionally to their contributions.

However, the purpose of this article has been neither to promote specific reforms to corporate law, nor to develop a legal framework for stakeholder theory. Instead, our objective has been to challenge the ever-growing prevalence of the standard corporate model. Our aim has been to outline theoretical frameworks that could be effectively used to establish pluralist models capable of creating both social and economic value. 
Aglietta, M., and Rebérioux, A. (2005) Corporate Governance Adrift: A Critique of Shareholder Value: (Cheltenham: Edward Elgar).

Alchian, A.A., and Demsetz, H. (1972) Production, Information costs and economic organization, The American economic Review, December, pp. 777-795.

Allen, F., and Gale, D. (2000) Corporate governance and competition, in: X. Vives (Ed.) Corporate governance. Theoretical and empirical evidences: (Cambrige: Cambrige University Press).

Barnard, C.I. (1968) The functions of the executive: (Cambrige: Harvard University Press).

Batsch, L. (2002) Le capitalisme financier (Paris: La Découverte).

Becker, G. (1964) Human Capital: a Theoretical and Empirical analysis: (New-York: Columbia University Press).

Blair, M. (1995) Ownership and Control: Rethinking Corporate Governance for the Twenty-First Century (Washington: Brookings Institution Press).

Blair, M.M., and Stout, L.A. (1999) A Team Production Theory of Corporate Law? Journal of Corporation Law, Vol. 24, nº 4, pp. 751- 807.

Blair, M.M., and Kochan, T.A. (2000) Human Capital in the American Corporation. (Washington: Brookings Institution Press).

Blair, M.M. (2005) Institutionalists, neoclassicals and team production, British Journal of Industrial Relations, Vol. 43, n²4, pp. 605-616.

Bloch-Lainé, F. (1963) Pour une réforme de l'entreprise (Paris: Seuil).

Bradley, M., Schipani, C.A., Sundaram, A.K., and Walsh, J.P. (1999) The purpose and accountability of the corporation in contemporary society: corporate governance at a crossroads, Law Contemporary Problems, Vol. 62, n³, pp.9-86.

Coriat, B., and Weinstein, O. (1995) Les nouvelles théories de l'entreprise: (Paris: Le livre de poche).

David, A., Hatchuel, A., and Laufer, R. (2000) Les nouvelles fondations des sciences de gestion. Eléments d'épistémologie pour la recherche en management: (Paris: Vuibert).

Donaldson, T., and Preston, L.E. (1995) The stakeholder theory of the corporation: concepts, evidence and implications, Academy of Management Review, Vol. 20, n¹, pp.65-91.

Gide, C. (1910) La Coopération, conférences de propagande: (Paris: Sirey).

Gide, C. (1911) Cours d'économie politique: (Paris: Recueil Sirey).

Gréau, J.-L. (2005) L'avenir du capitalisme (Paris: Gallimard).

Hansmann, H., and Kraakman, R. (2000) The End Of History For Corporate Law, Yale Law School Working Paper, No. 235, January.

Hart, O. (1995) Corporate governance: some theory and implications, Economic Journal, Vol. 105, n 430 , pp. 678-689.

Hatchuel, A., and Weil, B. (1995) Experts in Organization, a Knowledge-Based Perspective on Organizational Change (Berlin, New York: Walter de Gruyter).

Hatchuel, A. (2001) Towards Design Theory and expandable rationality: the unfinished program of Herbert Simon, Journal of management and governance, $\mathrm{n}^{\circ} 1$.

Hatchuel, A. (2004) Histoire des révolutions de la gestion des entreprises, Problèmes économiques, $\mathrm{n}^{\circ}$ 2852, 26 mai.

Hatchuel, A., and Segrestin, B. (2007) La société contre l'entreprise? Vers une nouvelle norme d"'Entreprise de progrès collectif", Droit et Société, nº5, pp.27-51.

Hill, C.W.L., and Jones, T.M. (1992) Stakeholder-agency theory, Journal of Management Studies, Vol.29, pp. 131-154.

Jensen, M.C., and Meckling, W.H. (1976) Theory of the firm: managerial behavior, agency costs and ownerships structure., Journal of Financial Economics, vol. 3, n 4, pp. 305-360.

Jones, T.M., and Wicks, A.C. (1999) Convergent Stakeholder Theory, Academy of Management Review, Vol. 24, n², pp. 206-231.

Kaufman, A., and Englander, E. (2005) A team production model of corporate governance, Academy of Management Executive, Vol. 19, $\mathrm{n}^{\circ} 3$, pp. 9-24.

Kochan, T.A. (1999) Exit, voice, loyalty in the course of corporate governance and counsel's changing role, Journal of Socio-Economics, Vol. 28, $\mathrm{n}^{\circ} 3$.

Kochan, T.A., and Rubinstein, S.A. (2000) Toward a stakeholder theory of the firm: the Saturn partnershhip, Organization Science, Vol. 11, n 4 July-August, pp. 367-386.

Krafft, J., and Ravix, J.-L. (2005) The governance of innovative firms: an evolutionary perspective, 
Economics of Innovation \& New Technology, Vol. 14, n³ (April), pp. 125-147.

Laufer, R. (2007) Crisis Management and Legitimacy: Facing Symbolic Disorders, in: C.M. Pearson,C. Roux-Dufort, and J.A. Clair (Eds.) International handbook of organizational crisis management. (Thousand Oaks: Sage).

Logue, J., and Yates, J. (2001) The Real World of Employee Ownership (Ithaca, N.Y.: Cornell University Press).

Menjuck, M. (2005) Corporate Governance Issues in France, European Business Law Review, pp. 10031016.

Paillusseau, J. (1967) La société anonyme: technique juridique d'organisation de l'entreprise (Paris: Sirey).

Parkinson, J. (2003) Models of the Company and the Employment Relationship, British Journal of Industrial Relations, Vol. 43, n³, pp. 481-509.

Penrose, E.T. (1959) The Theory of the Growth of the Firm (Oxford, UK: Basil Blackwell).

Post, J.E., Preston, L.E., and Sachs, S. (2002a) Managing the Extended Enterprise: The New Stakeholder View., California Management Review, Vol. 45, n¹, pp. 6-28.

Post, J.E., Preston, L.E., and Sachs, S. (2002b) Redefining the corporation: stakeholder management and organizational wealth (Stanford: Stanford University Press).

Rebérioux, A. (2003) Les marchés financiers et la participation des salariés aux décisions, Travail et emploi, n93, Janvier, pp. 25-44.

Ripert, G. (1951) Aspects juridiques du capitalisme moderne, deuxième édition, (Paris: LGDJ).

Roberts, J., McNulty, T., and Stiles, P. (2005) Beyond agency conceptions of the work of nonexecutive director: creating accountability in the boardroom, British Journal of Management, Vol. 16, S5-S26.

Saintourens, B. (1987) La flexibilité du droit des sociétés, Revue trimestrielle de Droit commercial, vol. 40, $\mathrm{n}^{\circ} 4$, pp. $457-494$.

Schleifer, A., and Vishny, R.W. (1986) Large Shareholders and Corporate Control, Journal of Political Economy, Vol. 94, n³, pp. 461-489.

Segrestin, B. (2005) Partnering to explore: the Renault-Nissan Alliance as a forerunner of new cooperative patterns, Research Policy, Volume 34, n5, pp. 657-672.

Segrestin, B. (2006) Innovation et coopération interentreprises. Comment gérer les partenariats d'exploration? (Paris: CNRS Editions).

Shleifer, A., and Vishny, R.W. (1997) A Survey of Corporate Governance, Journal of Finance, Vol. 52, $\mathrm{n}^{\circ} 2$, pp. 737-783.

Stoney, C., and Winstanley, D. (2001) Stakeholding: confusion or utopia? Mapping the conceptual terrain, Journal of Management Studies, Vol. 38, n5 5, pp. 603-626.

Szramkiewicz, R. (1989) Histoire du droit des affaires: (Paris: Montchrestien).

Winkler, A. (2004) Corporate Law or the Law of Business? Stakeholders and Corporate Governance at the End of History, Journal of Law and Contemporary Problems, Vol. 67, pp. 109-133. 


\begin{tabular}{|l|l|}
\hline Members in the corporation & Members in the ECP framework \\
\hline Shareholders and directors & $\begin{array}{l}\text { All individuals contributing to collective action, } \\
\text { each individual contribution calling for fair } \\
\text { retribution (dividends, wages, etc.). }\end{array}$ \\
\hline
\end{tabular}

Table 1: membership

\begin{tabular}{|l|l|}
\hline Profit-sharing in the public corporation & Potential-sharing in the ECP framework \\
\hline $\begin{array}{l}\text { Shareholders are the entitled beneficiaries of the } \\
\text { capital of the firm }\end{array}$ & $\begin{array}{l}\text { The firm intends to produce both individual and } \\
\text { collective potentials. Its members can benefit } \\
\text { from both, } \\
\text { i) depending on managerial decisions (which } \\
\text { potentials are developed); } \\
\text { ii) provided that they actually contribute with } \\
\text { their potentials (potentials are shared in } \\
\text { proportion to individual potentials); } \\
\text { iii) and to the extent that the potentials created } \\
\text { are shared with other members and with the } \\
\text { collective entity. }\end{array}$ \\
\hline
\end{tabular}

Table 2: Profit or potential-sharing

\begin{tabular}{|l|l|}
\hline Board members in the corporation & Board members in the ECP framework \\
\hline $\begin{array}{l}\text { Managers are accountable exclusively to } \\
\text { shareholders. }\end{array}$ & $\begin{array}{l}\text { All members have access to management when : } \\
\text { i) they provide sufficient individual potential } \\
\text { ii) they demonstrate effective commitment and } \\
\text { subordinate their potential to managerial } \\
\text { decisions. }\end{array}$ \\
$\begin{array}{l}\text { Voting rights are proportionate to the amount of } \\
\text { shares, which are freely transferable. }\end{array}$ & $\begin{array}{l}\text { Voting rights are proportionate to the potentials } \\
\text { that are shared, including the collective potentials } \\
\text { (which can give additional voting rights to } \\
\text { managers). }\end{array}$ \\
\hline
\end{tabular}

Table 3: management participation and board members 
${ }^{1}$ See in particular (Szramkiewicz, 1989).

${ }^{2}$ The US case has followed a quite similar pattern according to various sources, e.g. (Blair, 2005).

${ }^{3}$ It should be noted that elaborate credit mechanisms had not yet been developed at this point in history. Merchant banks only appeared in the $19^{\text {th }}$ century.

${ }^{4}$ Similar ideas have been advanced by a number of commentators, including (Gréau, 2005; Paillusseau, 1967; Ripert, 1951).

${ }^{5}$ This is consistent with the analysis of Blair and Stout who consider that the corporation is actually the residual owner of the surplus generated by team production (Blair and Stout, 1999).

${ }^{6}$ As Blair and Stout convincingly demonstrate, in order to be effective, the members of the team have to subordinate their inputs. The authors refer to a transfer of control rights: "both team members might improve their welfare by agreeing to give up control rights to a third party (...) to the actual productive activity" (Blair and Stout, 1999).

${ }^{7}$ It should be noted that the three elements constituting the model depend on the expertise of and relationships between the actors involved in the firm. This model should therefore be regarded as a series of formal axioms describing collective action. Neither the nature nor the meaning of such action are presupposed. The model can, of course, evolve (Hatchuel, 2001).

${ }^{8}$ This approach has a notable precedent in the French civil service: the so-called "slipper rule" obliges graduates of the prestigious Polytechnique schools to pay a lump sum to the State if they fail to become civil servants after having undergone salaried training. 